\title{
Izolowany brodawczak odwrócony zatoki klinowej - opis przypadku
}

\author{
Isolated inverted papilloma of the sphenoid sinus - case report \\ Krzysztof Oleś, Maciej Wiatr, Paweł Stręk, Jacek Składzień, Jerzy Tomik, \\ Henryk Podziorny, Aleksandra Boroń, Joanna Szaleniec
}

\begin{abstract}
SUMMARY
Background: Primary inverted papilloma of the sphenoid sinus is rare. The tumor is considered locally aggressive. In selected cases inverted papilloma can be associated with squamous cell carcinoma. Radiologic imaging is a key to an accurate diagnosis.

Aim: We analyzed patient with inverted papilloma in sphenoid sinus which was removed with endoscopic surgery.

Material and methods: We discuss patient with isolated inverted papilloma located in the sphenoid sinus.

Results: Performed endoscopic treatment enabled removal of tumour with no complications.

Conclusions: Transnasal endoscopic large sphenoidotomy remains an effective modality for mangement of patients with inverted papilloma. This method does not require external approach and it is performed with no scars, with minimal injury of tissues.

Hasła indeksowe: brodawczak odwrócony, zatoka klinowa, chirurgia endoskopowa zatok przynosowych

Key words: Inverted papilloma, sphenoid sinus, endoscopic paranasal surgery
\end{abstract}

Qby Polskie Towarzystwo Otorynolaryngologów - Chirurgów Głowy i Szyi Otrzymano/Received:

16.02.2011

Zaakceptowano do druku/Accepted: 04.05.2011

Katedra i Klinika Otolaryngologii

Uniwersytet Jagielloński Collegium Medicum Kierownik: Prof. dr hab. Jacek Skladzień

Wkład pracy autorów/Authors contribution: Dr med. Krzysztof Oleś - główny badacz, prof. Paweł Strek i prof Jacek Składzień - nadzór nad badaniami i interpretacją wyników, dr med. Maciej Wiatr, dr med. Jerzy Tomik, dr med. Henryk Podziorny, lek. med. Aleksandra Boroń, lek. med. Joanna Szaleniec - udział w gromadzeniu i analizie zebranych danych

Konflikt interesu/Conflicts of interest:

Autorzy pracy nie zgłaszają konfliktu interesów.

Adres do korespondencji

Address for correspondence:

imię i nazwisko: Krzysztof Oles

adres pocztowy:

Katedra i Klinika Otolaryngologii

Uniwersytet Jagielloński Collegium Medicum

ul. Śniadeckich 2

31-531 Kraków

tel. $(+12)$ 424-79-00

ax (+12) 424-79-25

e-mail olokrista@op.p

\section{Wstęp}

Brodawczak odwrócony (IP) jest rzadkim guzem pochodzenia nabłonkowego o łagodnym charakterze, wykazujacym cechy miejscowo agresywnego wzrostu oraz tendencję do nawrotu $(0,5-4 \%$ wszystkich pierwotnych guzôw nosa i zatok przynosowych) [1-3]. Spośród wszystkich lokalizacji występowania tego guza tylko $5 \%$ obejmuje zatoki przynosowe. Większość opisywanych przypadkôw dotyczy zatoki szczękowej i komórek sitowych. Pierwotna lokalizacja brodawczaka odwróconego w zatoce klinowej należy do wyjątkowej rzadkości. Przedstawiamy leczenie tak umiejscowionego guza o dużym, miejscowym zaawansowaniu $\mathrm{z}$ uwagi na skalę trudności zabiegu operacyjnego.

\section{Opis przypadku}

71-letni chory skierowany został do Klinik Otolaryn gologii CM UJ w Krakowie $z$ Kliniki Neurotraumatologi CM UJ z powodu podejrzenia procesu rozrostowego (przerzutu nowotworu), celem weryfikacji histopatologicznej i ustalenia dalszego leczenia.

Przy przyjęciu pacjent skarżył się na silne bóle głowy okolicy czołowej i ciemieniowej, bóle zagałkowe, trudności w oddychaniu przez nos, anosmię, zaburze nia ruchomości gałki ocznej, podwójne widzenie we wszystkich kierunkach. W wywiadzie zgłaszał ponadto nadciśnienie tętnicze, chorobę niedokrwienną serca, miażdżycę uogólnioną, POCHP, żylaki kończyn dolnych. U chorego tego 3 lata wcześniej usunięto gruczoł krokowy $z$ powodu adenocarcinoma $z$ następowym leczeniem hormonalnym. Chory miał znacznego stopnia nadwagę.

W badaniu otolaryngologicznym nie stwierdzono istotnych odchylen od normy.

W MRI opisano rozdęcie zatoki klinowej po stronie prawej $z$ widocznymi masami patologicznymi o wymiarach $36 \times 28 \times 31 \mathrm{~mm}$, które wypełniały całe światło zatoki, w tym również zachyłek boczny. Obraz radiologiczny był niejednoznaczny i nakazywał uwzględnić w diagnostyce różnicowej adenocarcinoma oraz lymphoma (Ryc. 1. Ryc. 2.).

W CT zatok przynosowych w porównaniu z MRI obraz opisywanej nieprawidłowości w rozdętej zatoce klinowej istotnie się nie różnił. Tomografia wykazała, że zmiana wypełnia także zachyłek boczny, ma wymiary $34 \times 28 \times 28$ mm, niejednorodną gęstość i wykazuje mierne wzmocnienie po kontraście $z 36$ do 58 jednostek Hounsfielda. Obraz zmiany, jak i ubytków kostnych w ograniczeniu zatoki był niejednoznaczny (Ryc. 3. Ryc. 4.).
Otolaryngol Pol 2011; 65 (4): $293-296$ 


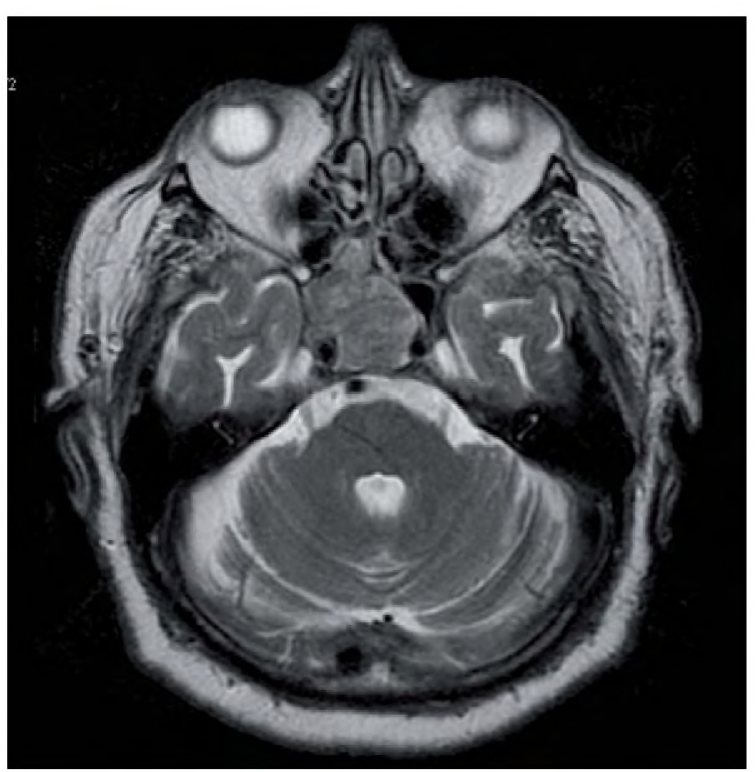

Ryc. 1. Izolowany brodawczak odwrócony zatoki klinowej; $\mathrm{MRI}$ - plaszczyzna poprzeczna

Fig. 1. Isolated inverted papilloma of the sphenoid sinus; MRI - horizontal plane

Wykonano sphenoethmoidektomię prawostronną. $Z$ uwagi na duże krwawienie śródoperacyjne i zły stan ogólny pacjenta zabieg był trudny technicznie. Operacje przeprowadzono w hypotensji, obniżając ciśnienie tęt nicze nitrogliceryną i ebrantilem, uzyskując tą drogą zadawalające warunki operacyjne. Śródoperacyjnie stwierdzono dehiscencje w bocznej (widoczne tętnienie opony mózgowia) i dolnej ścianie zatoki klinowej. Górne ograniczenie zatoki, podstawa czaszki była niezmieniona. Przednią ścianę zatoki zniesiono, tak jak to było możliwe, do boku i dołu aż do dna zatoki klinowej.

Podwójne widzenie ustąpiło już w 1. dobie po usu nięciu opatrunku z jamy nosowej. Pacjent wypisany został z Kliniki w 3. dobie od operacji w obstawie antybiotykowej. W tracie badania kontrolnego 12 miesięcy od zabiegu nie stwierdzono cech wznowy. Pacjent pozostaje pod stałą, comiesięczną kontrolą endoskopową w tutejszej Klinice oraz Klinice Onkologii z powodu choroby nowotworowej. W badaniu histopatologicznym, w materiale pochodzacym $z$ komórek sitowych po stronie prawej stwierdzono fragmenty błony śluzowej górnych dróg oddechowych $\mathrm{z}$ niewielkim nieswoistym naciekiem zapalnym i ziarniną w podścielisku. W preparacie pochodzacym $z$ zatoki klinowej opisano papil loma inversum. Pierwotnie planowana biopsja okazała się być radykalną operacją.

\section{Omówienie}

Brodawczak odwrócony jest łagodnym guzem bocznej ściany jamy nosowej i zatok przynosowych. Po raz

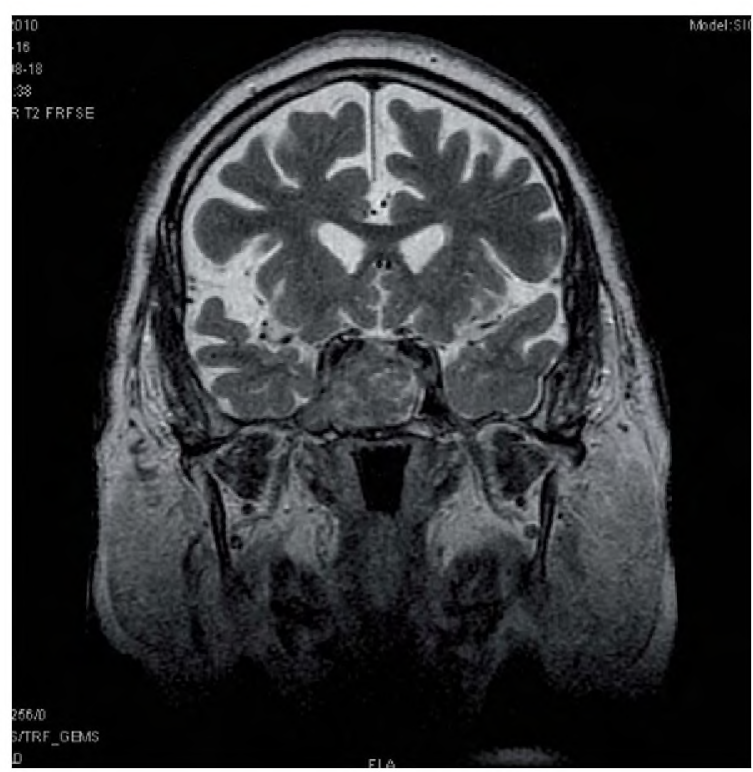

Ryc. 2. Izolowany brodawczak odwrócony zatoki klinowej; MRI - płaszczyzna czolowa

Fig. 2. Isolated inverted papilloma of the sphenoid sinus; MRI - frontal plane

pierwszy został opisany przez Warda w roku 1854 oraz rok później przez Bilrotha [1]. W 1935 roku Kramer i Som wykazali odmienność patologii brodawczaka odwróconego w stosunku do zapalnych polipów, a w roku 1938 Rigertz odkrył jego skłonność do odwrôconego wrastania $w$ podłoże $[2,4]$.

Tylko 5\% tych guzów ograniczone jest wyłącznie do zatok przynosowych. W 50\% do 80\% przypadków zajęte sa komórki sitowe i zatoka szczekowa. Ponad $80 \%$ PI obejmuje zarôwno jamę nosa, jak i zatoki przynosowe. Najczęściej choruja pacjenci rasy białej między 50. a 70. rokiem życia, znane są jednakże przypadki występowania schorzenia między 6. a 91. rokiem życia. Brodawczak odwrócony jest 2-4 razy częściej opisywany u mężczyzn niż kobiet. W badaniu fizykalnym prezentuje się jako miękkotkankowy, szaro-różowy, kruchy, łatwo krwawiący guz mogacy sięgać od nosogardła aż do nozdrzy przednich. Guz najczęściej ma kontakt $\mathrm{z}$ boczną ścianą jamy nosowej, przylegając do małżowiny nosowej środkowej, do tyłu od wyrostka haczykowatego. Rozmiary spotykanych guzów sięgają od kilku milimetrôw do ponad $10 \mathrm{~cm}$ [5].

Nie wykazano związku guza $z$ alergią, nikotynizmem, narażeniem zawodowym na substancje toksyczne [6]. Czynniki etiologiczne powstania tego nowotworu nie są znane. Sugeruje się pochodzenie wirusowe guza, zwłaszcza możliwy związek z zakażeniem wirusami HPV typu 6, 11, 16, 18 [7, 8]. Beck i wsp. potwierdzili większą skłonność brodawczaków odwróconych, z których wyizolowano HPV typu 16 i 18 , do transformacji w kierunku raka płaskona- 


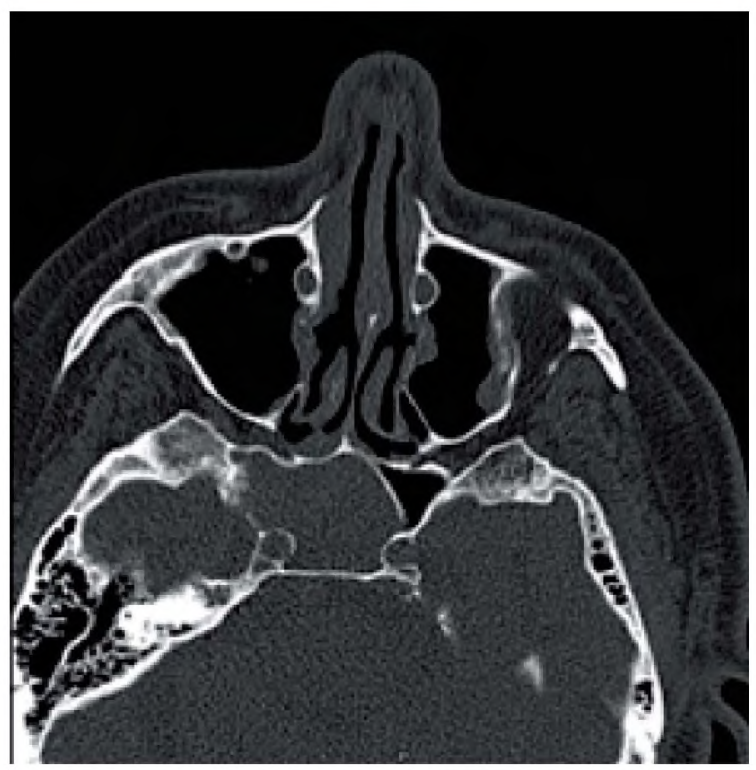

Ryc. 3. Izolowany brodawczak odwrócony zatoki klinowej; TK - plaszczyzna poprzeczna

Fig. 3. Isolated inverted papilloma of the sphenoid sinus; CT - horizontal plane

błonkowego w porównaniu z zakażeniem HPV typu 6 i $11[7,9]$.

W postaci łagodnej brodawczaka odwróconego mi tozy komórkowe są rzadkie - indeks mitotyczny jest niższy niż 1 na pole widzenia. Liczba wrzecion podziału oraz obecność przestrzeni wypełnionych śluzem jest niewielka, a stosunek ilości komórek nabłonkowych do komórek tkanki łącznej jest wysoki [8]. Postać bardziej złośliwa wiąże się z przewaga dojrzałego nabłonka płaskiego, nadmiernym rogowaceniem, indeksem mitotycznym $>2 \mathrm{w}$ polu widzenia. Zwykle postać ta nie współistnieje $z$ polipami zapalnymi [8].

Brodawczak odwrócony wywodzi się z pozostałości embrionalnej błony Schneidera, współtworzącej boczną ścianę jamy nosowej. W obrazie histopatologicznym dominuje proliferacja oraz endofityczne, odwrócone wrastanie palczystych wy pustek pogrubiałego nabłonka płaskiego w głąb wolnego od obrzęku podścieliska. Nabłonek ten nie posiada gruczołów śluzowych, błona podstawna jest prawidłowej grubości, nie ma cech hialinizacji, wyraźnie odróżnia się od tkanki łącznej podłoża $[6,7]$. W nacieku jednak brak jest eozynofilôw i obrzęku podścieliska [10]. Diagnostyka różnicowa obejmuje przewlekłe zapalenia zatok, mukocele, infekcje grzybicze oraz guzy łagodne i złośliwe. Rozpoznanie jest wyłącznie histopatologiczne.

Izolowane schorzenia zatoki klinowej występuja rzadko. Ze względu na etiologię zostały podzielone na niezapalne i zapalne. Do pierwszej grupy zaliczono nowotwory, w tym gruczolaki przysadki, raki gruczołowe, guzy naczyniowe, guzy wywodzące się z tkanki

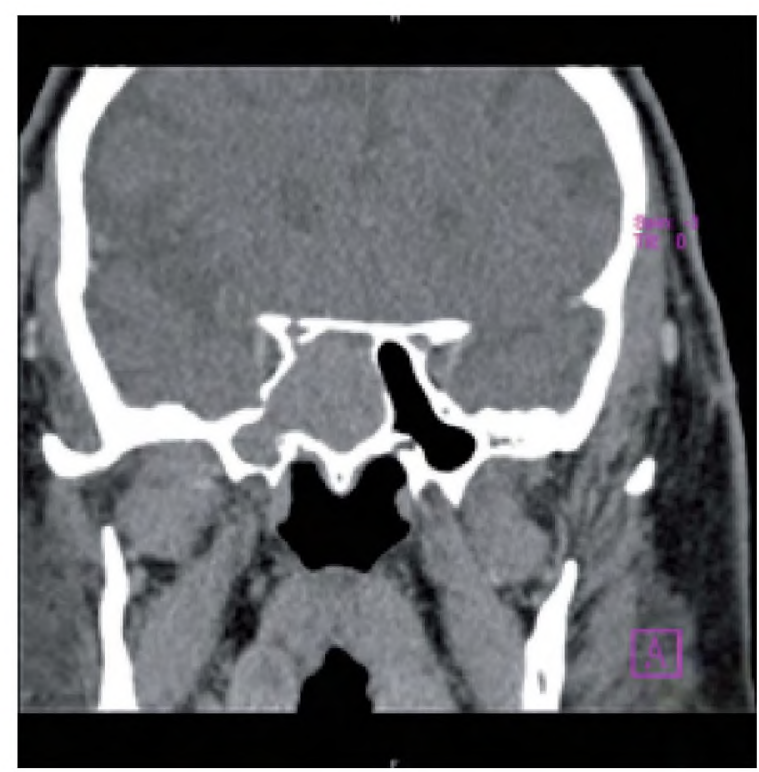

Ryc. 4. Izolowany brodawczak odwrócony zatoki klinowej; TK - plaszczyzna czołowa

Fig. 4. Isolated inverted papilloma of the sphenoid sinus; CT - frontal plane

kostnej, brodawczaki odwrócone. Druga, liczniejsza grupę tworzą zakażenia bakteryjne, infekcje grzybicze.

Do tej pory niewiele, bo ponad 50 przypadków izolowanych brodawczaków odwróconych zostało opisanych w zatoce klinowej. W 1926 roku Vogel opisał 1. przypadek, a w 1971 roku Edison opublikował 2. brodawczaka odwróconego w zatoce klinowej. McElveen i Fee opublikowali 3. przypadek w 1981 roku. Następnie Sethi przedstawił 2 przypadki tych guzów. Oba były leczone endoskopowo, wykonano sphenoidektomię [11]. Zabiegi te rutynowo wykonuje się w znieczuleniu ogólnym, w kontrolowanym podciśnieniu.

Objawy ograniczonego brodawczaka odwrôconego zatoki klinowej nie są charakterystyczne i powodują późną diagnozę. Najczęściej pacjenci podają niespecyficzne dolegliwości, podobne do towarzyszacych innym izolowanym schorzeniom tej zatoki, jak mukocele czy grzybice.

Wczesne stadia zajęcia zatoki klinowej to bóle głowy okolicy potyliczno-czołowej, bóle zagałkowe promieniujące do szyi. W bardziej zaawansowanych stadiach dołączają się objawy zajęcia nerwów czaszkowych, manifestujące się podwójnym widzeniem, upośledzeniem ostrości widzenia oraz bóle twarzoczaszki.

W badaniach obrazowych brodawczak odwrócony przedstawia się jako jednostronne masy zajmujące boczną ścianę jamy nosowej z zatokami przynosowymi. W 70\% przypadków obserwuje się destrukcje kostne w najbliższej okolicy.

Obraz brodawczaka odwróconego w tomografii komputerowej jest różnorodny, a czułość ustalenia 
rozpoznania wynosi ok. $70 \%$ i jest zbliżona do śródope racyjnej oceny endoskopowej. Specyficzność kształtuje się na poziomie $20 \%$. Najczęściej widoczne są masy o nierównej powierzchni, z kalcyfikacją widoczną wewnatrz guza, ze ścieńczeniem ograniczeń kostnych, ich ubytkami oraz hyperosteozą. Sirkici, analizując 92 pacjentów z izolowanym zajęciem zatoki klinowej, stwierdził aż 22,8\% ubytków kostnych dotyczących kanału nerwu wzrokowego i tętnicy szyjnej wewnętrznej. Jako przyczynę podał nie tylko ucisk guza, ale i towarzyszący przewlekły stan zapalny $z$ działaniem cytokin mediatorów zapalenia stymulujących aktywność osteoblastôw i osteoklastów [7].

Brodawczak odwrócony charakteryzuje się potencjalną możliwością przemiany nowotworowej. Najczęściej, w 7-15\% przypadków, ulega przemianie w raka płaskonabłonkowego. Postępowaniem $z$ wyboru jest resekcja chirurgiczna guza wraz $z$ oznaczeniem marginesów radykalności onkologicznej. Większość wznôw ma miejsce w pierwszych 2 latach po leczeniu, choć obecne doniesienia dotyczace zatoki klinowej podają, że najwięcej wznów obserwuje się w pierwszych 3 miesiącach po operacji. Nawroty i reoperacje szacowane są na $14-71 \%$.

Dojścia zewnętrzne, w tym rynotomię boczną czy maxillektomię przyśrodkowa charakteryzuje ten sam odsetek wznôw. Nie ma jednoznacznych wytycznych co do wyboru metody dojścia chirurgicznego dla izolowanych brodawczaków zatoki klinowej, ale dojście endoskopowe wydaje się być polecane.

Brodawczak odwrócony ma tendencję do wzrostu do jamy nosa, dlatego objawy ze strony jamy czaszki czy oczodołu są rzadziej spotykane [12]. Objawy oczne, ta kie jak diplopia oraz zaburzenia ostrości widzenia, wynikają z zajęcia nerwów czaszkowych. Diplopia wynika $\mathrm{z}$ porażenia nerwu VI, przebiegającego $\mathrm{w}$ bezpośrednim sąsiedztwie bocznej ściany zatoki klinowej w kanale Dorello, w przyśrodkowej części zatoki jamistej [13]. Usunięcie guza zatoki klinowej powoduje zmniejszenie kompresji na nerwy czaszkowe i ustąpienie dolegliwości.

\section{Wnioski}

1. Obecność destrukcji ścian kostnych zatoki klinowej widoczna w CT powinna budzić podejrzenie brodawczaka odwróconego lub wznowy po przebytym leczeniu.
2. Boczna ściana zatoki klinowej i jej dno to typowe lokalizacje wznów brodawczaka odwróconego.

3. Nie ma jednoznacznych wskazań co do wyboru metody dojścia chirurgicznego dla izolowanych brodawezaków odwróconych zatoki klinowej, ale dojście endoskopowe wydaje się być godne polecenia.

\section{P I ŚM I E N N I C T W O}

1. Phillips PP, Gustafson RO, Facer GW: The Clinical Behavior of Inverted Papilloma of the Nose and Paranasal Sinuses: Report of 112 Cases and Review of the Literature. Laryngoscope 1990; 100:463-469.

2. Socher JA, Cassano M, Filheiro CA et al.: Diagnosis and treatment of isolated sphenoid sinus disease: a review of 109 cases. Acta Oto-Laryngol 2008; 128:1004-1010.

3. Stręk P, Zagólski O: Zastosowanie chirurgii endoskopowej w leczeniu brodawczaka odwróconego jamy nosowej. Mag. ORL. 2003, 1(5):13-18.

4. Stręk P, Zagólski O, Składzień J et al.: Endoskopowe leczenie chorych $z$ izolowanymi stanami patologicznymi zatoki klinowej. Otolaryngol Pol 2007, 3:254-259.

5. Woodruff WW, Vrabec DP: Inverted papilloma of the nasal vault and paranasal sinuses: spectrum of CT findings. AJR Am J Roentrenol 1994,162: 419-23.

6. Vrabec D: The Inverted Schneiderian Papilloma. A 25 year study. Laryngoscope; 1992, 102:917-922.

7. Stręk $P$, Zagólski $O$, Składzień $\mathbf{J}$ et al.: Our experience in treatment of patients with inverted papiloma of the lateral nasal wall. Otolaryngol Pol. 2003, 57:633-7.

8. Nielsen PL, Buchwald C, Nielsen LH et al.: Inverted papilloma of the nasal cavity: pathological aspects in a follow-up study. Laryngoscope; 1991, 101:1094-1101.

9. Mansell NJ, Bates GJ: The inverted Schneiderian papilloma: a review and literature report of 43 new cases. Rhinology 2000,38:97-101.

10. Keles N, Deger K: Endonasal endoscopic surgical treatment of paranasal sinus inverted papilloma - first experiences. Rhinology 2001, 39:156-159.

11. Lee JT, Bhuta S, Lufkin R et al.: Isolated Inverting Papilloma of the Sphenoid Sinus. Laryngoscope 2003,133:41-44.

12. Casiano RR: Transnasal endoscopic surgery for benign neoplasms of the nose and sinuses. Current opinion in otolaryngology \& head and neck surgery. 2001,9:37-41.

13. Bertrand B, Jorissen M, Rombaux Ph et al.: Surgery of inverted papillomas under endoscopic control. Acta otorhonolaryngologica belg. 2000,54:139-150. 